\title{
Activities of tabanids (Diptera, Tabanidae) attacking domestic duck-Cairina moschata (Linnaeus) (Aves, Anatidae), introduced in a forest area in the Central Amazon, Manaus, Brazil
}

\author{
Ruth L. M. Ferreira ${ }^{1} \&$ José A. Rafael $^{1}$
} 'Coordenação de Pesquisas em Entomologia, Instituto Nacional de Pesquisas da Amazônia/INPA. Caixa Postal 478, 69011-970
Manaus-AM, Brazil. E-mail: ruth@inpa.gov.br, jarafael@inpa.gov.br

\begin{abstract}
Aвstract. Presented here are the feeding habits, attack behavior, daily and annual activity of adult of Phorcotabanus cinereus (Wiedeman, 1821), Chrysops laetus (Fabricius, 1805) and Phaeotabanus cajennensis (Fabricius, 1787), while biting a domestic duck, Cairina moschata (Linnaeus, 1758). The last two species were recorded for the first time attacking birds. This study comprehended monthly observations of two consecutive days from April/97 to March/98 between 5:30 a.m. and 6:30 p.m. at the Army Instructional Base ((BI-2/CIGS) near Manaus. Annual occurrence of $P$. cinereus was from July to September, with a daily occurrence between 9:00 a.m. and 5:00 p.m. and highest activity at 12:00 a.m. and 2:00 p.m. C. laetus ocurred from June to October; with a daily occurrence between 8:00 a.m. and 3 p.m. and highest activity at 11:00 and 12:00 a.m. Occurrence of $P$. cajennensis with one specimen only, was in July between 10:00 and 11:00 a.m.
\end{abstract}

KEYwords. Amazon; domestic duck; horseflies; Tabanidae.

Resumo. Atividades de tabanídeos (Diptera, Tabanidae) atacando pato doméstico - Cairina moschata Linnaeus (Aves, Anatidae), introduzido em área de floresta na Amazônia Central, Manaus, Brasil. São apresentados o hábito alimentar, comportamento de ataque, atividade diária e anual de adultos de Phorcotabanus cinereus (Wiedemann, 1821), Chrysops laetus (Fabricius, 1805) e Phaeotabanus cajennensis (Fabricius, 1787) atacando pato doméstico - Cairina moschata (Linnaeus, 1758). As últimas duas últimas espécies são registradas pela primeira vez atacando aves. O estudo compreendeu observações mensais durante dois dias consecutivos de Abril/97 a Março/98, entre 5:30 e 18:30 h, na base de instrução 2 do Centro de Instrução de Guerra na Selva (BI-2/CIGS), Manaus. A ocorrência anual de $P$. cinereus, foi de julho a setembro, com atividade diária entre 9:00 e 17:00 horas, com maior abundância entre 12:00 e 14:00 horas. C. laetus, ocorreu de junho a outubro, com atividade diária entre 8:00 e 15:00 horas, e maior abundância entre 11:00 e 12:00 horas. A ocorrência de P. cajennensis com um espécime, foi em julho entre 10:00 e 11:00 horas.

Palavras-chave. Amazônia; mutucas; pato doméstico; Tabanidae.

Only few known species of tabanids possess hematophagous specificity for a single vertebrate species, and only a small number of papers on researches address the feeding specificity in this family (HeNRiQues et al. 2000; LiMEIRA-DE-OliveIRA et al. 2002). The majority of the species feed on large mammals (bovines and equines) (RAFAEL \& Charlwood 1980; Gorayeb 1985; Raymond \& Rousseau 1987; BARROs 2001), while a minority feed on reptiles or birds (MEDEM 1981; Philip 1983, 1986; Ferreira et al. 2002; Limeira-DEOliveira et al. 2002). Reasons for this diverse feeding habits are not clear and have been the object of various studies (MCKEEVER \& French 1999).

The present study is a contribution to the knowledge about the association of tabanid species with specific vertebrate hosts.

\section{MATERIAL AND METHODS}

This study was carried out in cooperation with the Brazilian Army, at the instruction base - Base de Instrução 2 ( $\left.02^{\circ} 45^{\prime} \mathrm{S} ; 59^{\circ} 51\right)$ of the Instruction Center for Jungle War - Centro de Instrução de Guerra na Selva (BI/2/CIGS), at km-54 AM-010 road, near Manaus. The experiment was installed in an anthropical clearing, surrounded by primary forest along the banks of Candiru stream. A duck, C. moschata (Linn., 1758), was used as bait. The wild version of this species occurs naturally in the Amazon and it is more common in large rivers and lakes. The domestic form is commercially exploited in all types of habitats.

The experiment was conduced together with another experiment, working with the exposition of other vertebrate hosts (jaguar, snake, tapir, alligator, bird, man), crowded in the same clearing.

Observations of two consecutive days between 5:30 a.m. and 6:30 p.m. were made on a monthly basis between April/97 and March/98. To analyze daily activity, we used the descriptive circular statistic, for testing the uniformity hypothesis of the distribution of populations (Rayleigh $\mathrm{z}$ test), with a significance level $\alpha<0.05$ (OrIANA - KovaCH Computing Services 1999). It was applied a test for correlation according to Spearman $r_{\mathrm{s}}(\alpha<0,05)$ (ZAR 1996; Fisher 2000; Jammalamadaka \& Sengupta 2001), between diurnal and annual abundance of horsefly species and temperature, relative humidity (measured in loco) and precipitation (provided 
by meteorological station of the EMPRAPA/Manaus/AM).

Our interpretation of the correlation coefficient was based on Rowntree (1984), and of climate variability of this region on Fish et al. (1998).

\section{RESULTS ANDDISCUSSION}

Fifty-one specimens pertaining to three species were collected while feeding on the duck. The most abundant was Phorcotabanus cinereus (Wiedemann, 1821), numbering 38 specimens (75\%), followed by 12 specimens (24\%) of Chrysops laetus Fabricius, 1805, and one specimen of Phaeotabanus cajennensis (Fabricius, 1787).

Phorcotabanus cinereus. The diurnal activity on the bird was between 9:00 a.m. and 5:00 p.m., with highest activity at 12:00 a.m. and 2:00 p.m. The mode of presentation of occurrence

Table I. Descriptive circular statistics for the Tabanidae species collected on the duck (C. moschata) during the course of the day at the Ducke Reserve.

\begin{tabular}{lll}
\hline \multicolumn{1}{c}{ Species } & C. laetus & P. cinereus \\
\hline Observatrions (n) & 12 & 38 \\
Mean vector () & $11: 24 \mathrm{am}$ & $12: 45 \mathrm{pm}$ \\
Length of mean vector ${ }^{\circledR}$ & 0,93 & 0,86 \\
Concentration & 5,21 & 3,79 \\
Circular variance & 0,07 & 0,14 \\
Deviation of circular variance & $01: 30 \mathrm{am}$ & $02: 07 \mathrm{am}$ \\
Standard mean error & $12: 31 \mathrm{am}$ & $12: 20 \mathrm{am}$ \\
95\% confidence interval & $10: 22 \mathrm{am}$ & $12: 04 \mathrm{pm}$ \\
(-/+) for $\mu$ & $12: 26 \mathrm{pm}$ & $01: 25 \mathrm{pm}$ \\
Rayleigh uniformity test $(\mathrm{p})$ & 0,00 & 0,00 \\
\hline
\end{tabular}

Table II. Correlation analysis of Spearman $\left(r_{s}\right)(\alpha \leq 0,05)$, of the abundance of the Tabanidae species collected on the duck, at B1/2, Manaus/AM, and climatic factors (temperature, relative humidity and precipitation) a) during the course of the day, and b) during the course of the year.

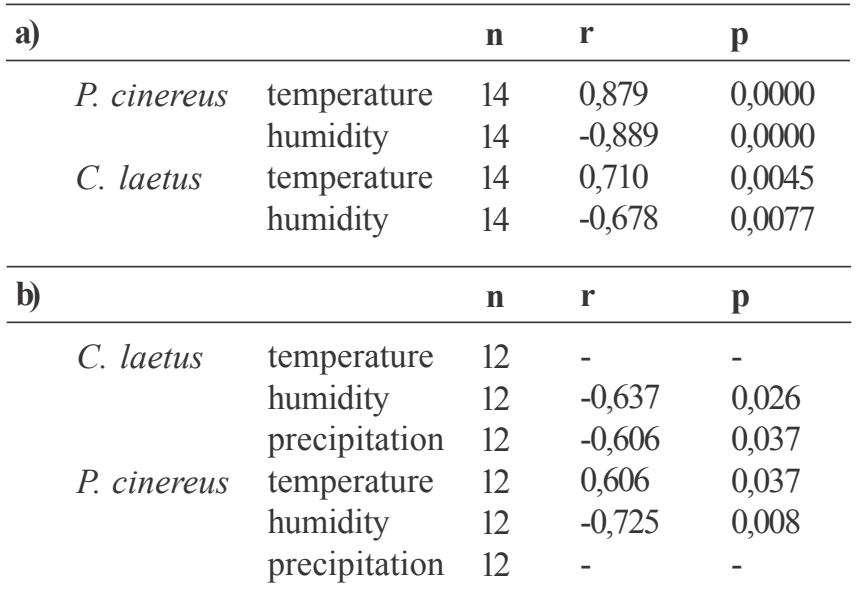

- There was no significant correlation, positive or negative.
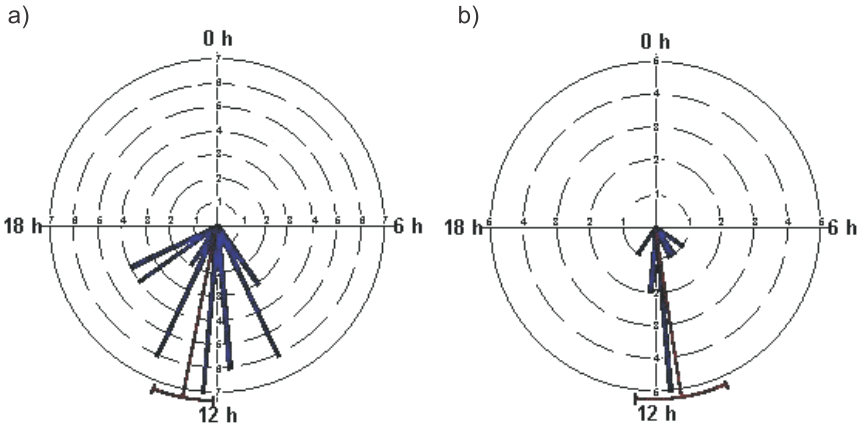

Fig. 1. Circular histogram representing daily activity of a) $P$. cinereus; b) $C$. laetus on the duck ( $C$. moschata). The line that follows the extreme arch represents the mean vector and the confidence interval, respectively.

(Fig. 1a) is a result of the Rayleigh test $z \mathrm{P}<0.001$ (Table I). The results show that species distribution was not uniform during the course of the day, presenting different timetable attack patterns. In $P$. cinereus, the correlation of abundance with temperature was positive $(\mathrm{r}=0.88, \mathrm{p}=0.00, \mathrm{n}=14)$ and a negative with relative humidity $(\mathrm{r}=-0.89, \mathrm{p}=0.00, \mathrm{n}=14)$ (Table IIa).

The annual occurrence was from July to September, showing highest density in August. This period corresponds to the months of lowest precipitation and highest temperature (Figs. 2, 4). During the year the activity of $P$. cinereus had positive correlation to temperature $(r=0.606, p=0.037, n=12)$ and a negative to relative humidity $(\mathrm{r}=-0.725, \mathrm{p}=0.008$, for $\mathrm{n}$ $=12$ ), however, none of these was significant. There was no correlation at all to precipitation (Table IIb).

We found the attacking behavior of $P$. cinereus being similar to the results obtained by LIMEIRA-DE-OLIVEIRA et al. (2002), as it attacked exclusively the duck, confirming itself as an ornithophilous species. Its behavior and attack area on the

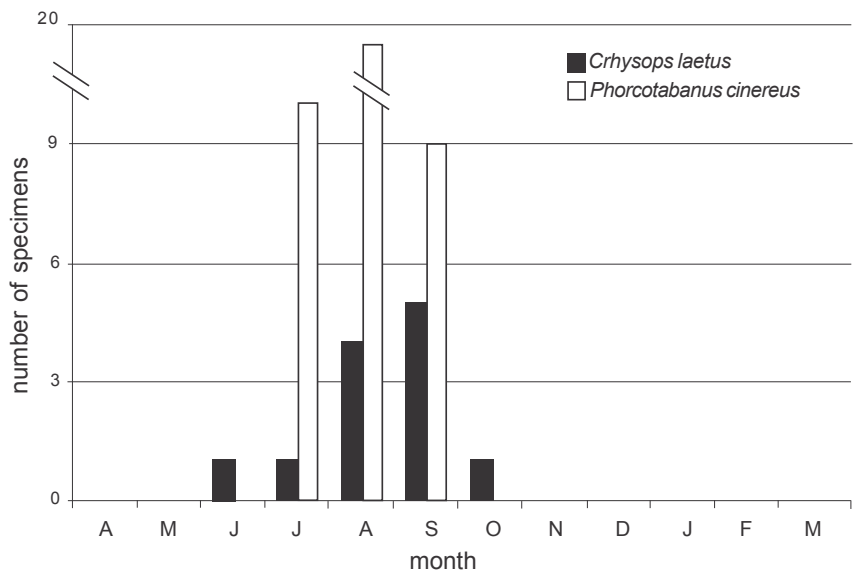

Fig. 2. Annual occurrence of two Tabanidae (Diptera) species collected on the duck (C. moschata), on the BI/2, Manaus/AM. 

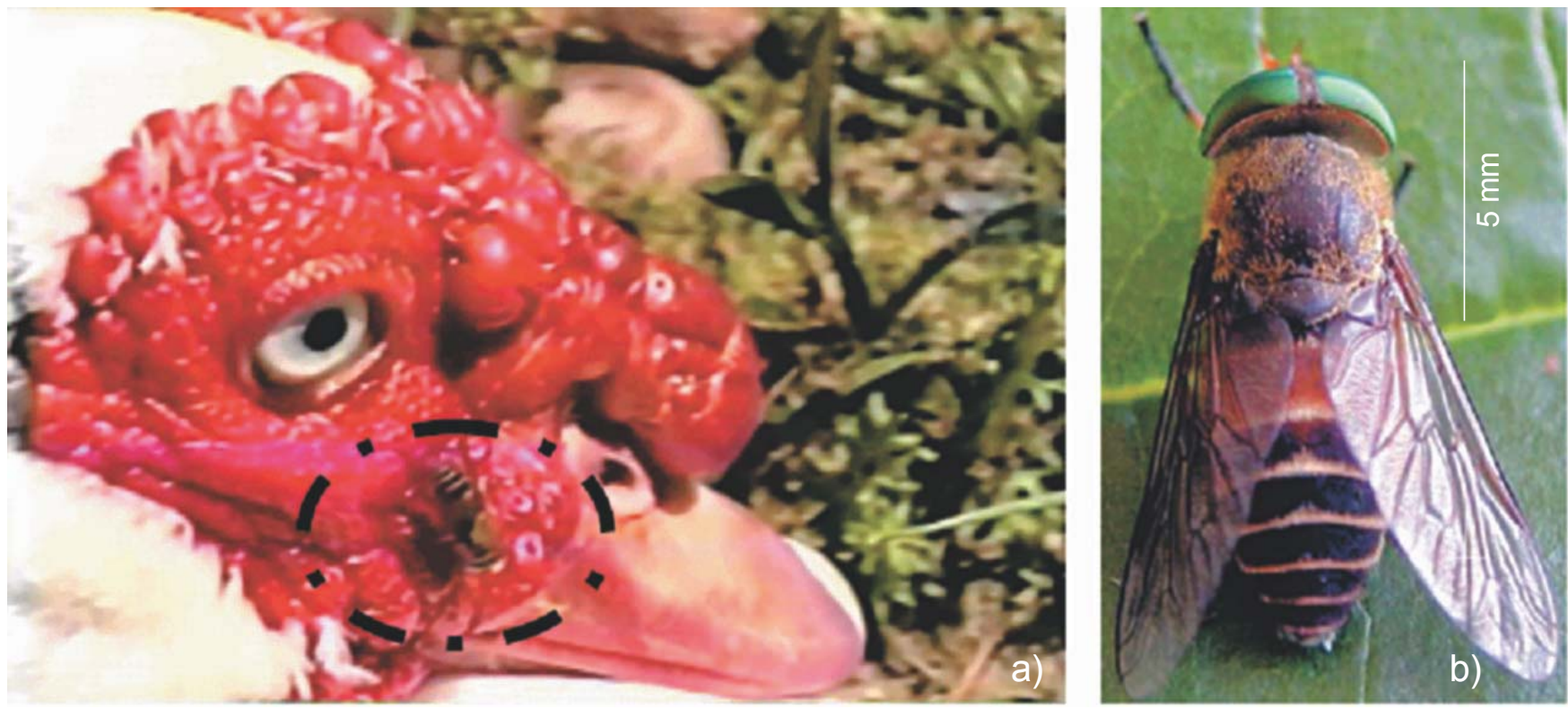

Fig. 3. a) P. cajennensis feeding on the duck (C. moschata), at the $\mathrm{BI} / 2$, Manaus/AM; b) dorsal view of P. cajennensis.

duck (caruncle), as well as its annual and diurnal occurrence corroborate the previous results of LiMEIRA-DE-Oliveira et al. (2002).

Chrysops laetus. The diurnal activity on the bird was between 8:00 a.m. and 3:00 p.m., with major density between 11:00 and 12:00 a.m. (Fig. 1b). Distribution was not uniform along the day (Rayleigh test z P d" 0,001) (Table I). There was positive correlation with temperature $\left(r_{s}=0,710, p=0,00, n=\right.$ 14) and negative with relative humidity $\left(r_{s}=-0,68, p=0,00, n=\right.$ 14) (Table IIa).

The annual occurrence of $C$. laetus was from June to October with major abundance in September, corresponding to the months of less precipitation and highest temperature (Figs. 2, 4). During the dry season, C. laetus presented a positive correlation with the temperature, a negative with

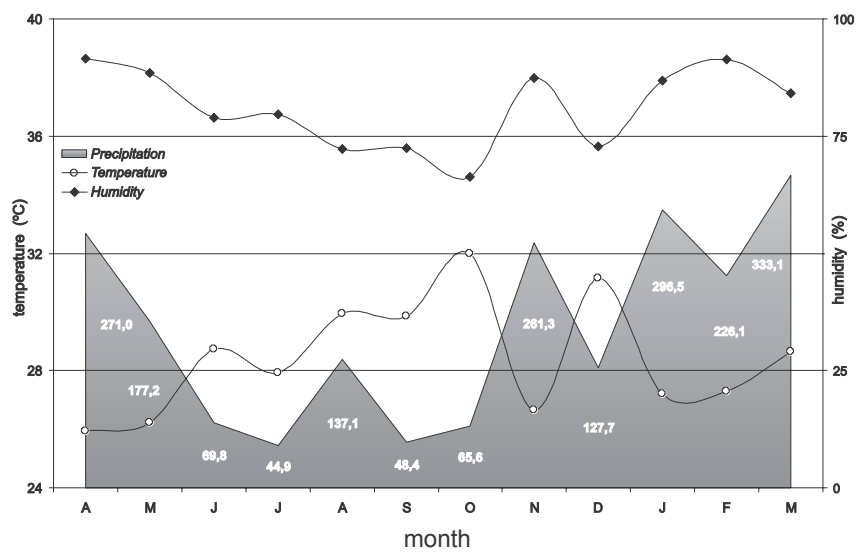

Fig. 4. Monthly data of relative humidity and temperature at the Instruction Base (BI/2), $\mathrm{AM} 010, \mathrm{Km} \mathrm{54}$; and precipitation $(\mathrm{mm})$ at the EMBRAPA station/ Manaus/AM. relative humidity $(\mathrm{r}=0.64, \mathrm{p}=0.026$, for $\mathrm{n}=12)$ and precipitation $(\mathrm{r}=-0.60, \mathrm{p}=0.037$, for $\mathrm{n}=12)$, but none of them were significant (Table IIb).

This specie flies around the body and lands on different parts, frequently above the feathers where it tries to bite, without success. When landing on the beak, the fly shifts to the caruncle where it takes its bloodmeal. C. laetus is a generalistic species because of its abundant attacks on other vertebrates, such as tapir Tapirus terrestris (Linn. 1758) (Tapiridae) and man. LimeirA-DE-Oliveira et al. (2002) also described the frequent attacks of this species on the duck, but they never observed any biting success. In Canada, representatives of the same genus were observed attacking crows, whose legs were bound (BENNETT 1960). Unbound, the crows generally catched the specimens before they landed to feed.

Phaeotabanus cajennensis. Only one specimen (Fig. 3b) was observed feeding on the duck (Fig. 3a) in July, between 10:00 and 11:00 a.m. This is the first record of this species on birds. Its behavior is similar to that of the previous recorded species, as it flies around the duck's head, landing on its beak and moving to the caruncle where it feeds. Generally, it prefers biting large mammals (bovines, equines) (BOUVIER 1952; RAFAEL 1982; RAYMOND \& Rousseau 1987; Barros 2001), shown by the frequent attacks on tapir (T. terrestris), and less frequent on man, what also was recorded by GoraYeB (1985). Perhaps the attack on the duck was accidental, but its successful feeding on birds shows $P$. cajennensis to be opportunist, because it could attack other hosts, when its preferred ones are not available.

The duck's defensive comportment. When annoyed by horseflies, it becomes anxious and defends itself by brusque, lateral head movements. It tries catching them with its beak, 
and occasionally has been successful. When nearby the water, it dislodges the flies by dipping its head into the water, temporarily alleviating itself. This behavior is similar to that described by LiMEIRA-DE-OLIVEIRA et al. (2002).

Acknowledgements. The authors express their appreciation to the Centro de Instrução de Guerra na Selva (CIGS) for logistical aid, João Ferreira Vidal for help in the field, Dr. José Camilo Hurtado Guerrero for collaboration in statistical analysis, George Nakamura for the English translation and Dr. Augusto L. Henriques for identifying the Tabanidae species and for collaborating in the field experiment.

\section{REFERENCES}

Barros, A. T. M. 2001. Seasonality and Relative Abundance of Tabanidae (Diptera) Captured on Horses in the Pantanal, Brazil. Memórias do Instituto Oswaldo Cruz 96(7): 917-923.

Bennett, G. F. 1960. On some ornithophilic blood-sucking Diptera in Algonquin Park, Ontario, Canada. Canadian Journal of Zoology 38: $377-389$.

Bouvier, G. 1952. Notes sur les Tabanidés de la Región de Campinas (Estado S. Paulo) Brésil. Memórias do Instituto Oswaldo Cruz 50: $581-596$

Ferreira, R. L. M.; A. L. Henriques \& J. A. Rafael. 2002. Activity of Tabanids (Insecta: Diptera:Tabanidae) Attacking the Reptiles Caiman crocodilus (Linn.) (Alligatoridae) and Eunectes murinus (Linn.) (Boidae), in Central Amazon, Brazil. Memórias do Instituto Oswaldo Cruz 97(1): 133-136.

Fisch, G.; J. A. Marengo \& C. A. Nobre. 1998. Uma revisão geral sobre o clima da Amazônia. Acta Amazonica 28(2): 101-126.

Fisher, N. I. 2000. Statistical Analysis of Circular Data. Cambridge, Press Syndicate of University of Cambridge, $277 \mathrm{p}$.

Gorayeb, I. S. 1985. Tabanidae (Diptera) da Amazônia Oriental. Sazonalidade, ataque e estratificação arbórea. Tese de doutorado. Instituto Nacional de Pesquisas da Amazônia / Fundação Universidade do Amazonas, xvi $+205 \mathrm{p}$.

Henriques, A. L.; R. L. M. Ferreira; J. F. Vidal \& J. A. Rafael. 2000. Betrequia ocellata Oldroyd (Diptera, Tabanidae, Rhinomyzini) blood feeding on Caiman crocodilus (Linnaeus) (Crocodylia, Alligatoridae) in Manaus, Brazil. Revista Brasileira de Zoologia 17(3): 609-613.

Jammalamadaka, S. R. \& A. SenGupta. 2001. Topics in Circular Statistics. World Scientific. Singapore, World Scientific Publishing Co. Pte. Ltd., 322 p.

Kovach, W. L. 1999. ORIANA for Windows 1.0. Kovach Computing Services, Pentraeth, Wales, UK.

Mckeever, S. \& F. E. French. 1999. Comparative study of Adult mouthparts of fifty-two species representing thirty genera of Tabanidae (Diptera), p. 327-353. In: J. F. Burger (ed.). Contributions to the Knowledge of Diptera. A collection of Articles on Diptera Commemorating the Life and Work of Graham B. Fairchild. Memoirs on Entomology International, vol. 14, 646 p.

Medem, F. 1981. Horse flies (Diptera:Tabanidae) as ectoparasites on caimans (Crocodylia:Alligatoridae) in eastern Colombia. Cespedesia 10(37-38): 123-191.

Limeira-de-Oliveira, F.; J. A. Rafael \& A. L. Henriques. 2002. Phorcotabanus cinereus (Wiedemann, 1821) (Diptera:Tabanidae) an Ornithophilic Species of Tabanid in Central Amazon, Brasil. Memórias do Instituto Oswaldo Cruz 97(6): 839-842.

Philip, C. B. 1983. A unique, divergent developmental dependence of a Galapagos horse fly (Diptera, Tabanidae). The Wasmann Journal of Biology 41(1-2): 47-49.

Philip, C. B. 1986. A collection of four species of tabanid flies taken from an Anaconda snake in Peru in May 1984. The Pan-Pacific Entomologist 62(1): 23.

RafaEL, J. A. 1982. Ocorrência sazonal e abundância relativa de Tabanidae (Diptera) no Campus Universitário, Manaus, Amazonas. Acta Amazonica 12(1): 225-229.

Rafael, J. A. \& J. D. Charwood. 1980. Idade fisiológica, variação sazonal e periodicidade diurna de quatro populações de Tabanidae (Diptera) no Campus Universitário, Manaus, Brasil. Acta Amazonica 10(4): 907-927.

Raymond, H. L. \& F. Rousseau. 1987. Abondance des taons (Diptera, Tabanidae) et réactions des bovins dans un élevage traditionnel de Guyane Française. Acta Ecologica Ecologia Applicata 8(2): 125134.

Rowntree, D. 1984. Introducction a la Estadistica. Un enfoque no matemático. Versão em espanhol de C. Chiappe \& E.V. Montoya, Cali, Ed. Norma, 137p.

ZAR, J. H. 1996. Biostatistical Analysis. $3^{\circ}$ ed. New Jersey, Prentice Hall International Editions, $662 \mathrm{p}$.

Received 24.VI.2003; accepted 30.III.2004 